\title{
Pytanie o miejsce religii w nowoczesnym państwie i społeczeństwie
}

\section{Lucyna Przybylska, Sakralizacja przestrzeni publicznych w Polsce, Wydawnictwo Uniwersytetu Gdańskiego, Gdańsk 2014, 366 s.}

Recenzowana książka pt. Sakralizacja przestrzeni publicznych w Polsce, wydana nakładem oficyny Uniwersytetu Gdańskiego w 2014 roku, to już kolejna, po opublikowanej w 2008 roku rozprawie nt. Zróżnicowania przestrzeni sakralnej Gdyni, propozycja Lucyny Przybylskiej z zakresu stosunkowo młodej dyscypliny naukowej, jaką jest geografia religii. Publikacja stanowi zwieńczenie wieloletnich badań Autorki - z wykształcenia geografa i teologa - nad oddziaływaniem religii na środowisko geograficzne oraz wpływem czynników geograficznych na religię. Rozprawa wpisuje się w obowiązujący współcześnie nurt badawczy - refleksję na temat wcześniejszych i aktualnie zachodzących zjawisk oraz zmian w przestrzeni publicznej, pośród których znajduje się między innymi sakralizacja, należąca do najbardziej wyraźnych i żywych procesów socjoprzestrzennych. Problem obecności sfery sacrum w przestrzeni nie jest nowy ani w polskiej, ani w światowej nauce, ale w rodzimym obiegu naukowym dotąd nie pojawiło się obszerniejsze czy bardziej pełne opracowanie tego tematu.

Uświęcenie miejsc publicznych jest zasadniczym przedmiotem rozważań Lucyny Przybylskiej. Przyjęta na potrzeby pracy definicja przestrzeni sakralnej wyraża jej procesualny i figuralny charakter. Autorka określiła ją jako: „wypełnianie owych [publicznych - I.L.-W.] przestrzeni obiektami i zjawiskami związanymi z religią, jak i samą obecność w nich obiektów i zjawisk związanych z religią" (s. 11). Pojęcie przestrzeni publicznej zostało potraktowane bardzo szeroko; jako obszar wspólny pod względem własnościowym i funkcjonalnym jest ona w przekonaniu $\mathrm{Au}-$ torki „nie tylko dobrem mającym specyficzne cechy użytkowe, ale także 
miejscem transmisji różnych produktów materialnych i niematerialnych zaspokajających różnorodne potrzeby społeczności lokalnych i ponadlokalnych" (s. 13). Epistemologiczny zakres rozważań obejmuje trzy rodzaje sakralizacji - architektoniczną, „(tym)czasową” (np. pielgrzym$\mathrm{ki}$, procesje) i nomenklaturową (nazewnictwo) - w rozprawie opisane w trzech rozdziałach, które odnoszą się do materialnych i niematerialnych dóbr kultury oraz swoistego połączenia obu form kulturowego istnienia. Stąd też istotą badań stały się miejsca mianowane świętymi, elementy językowe oraz rytuały, czyli urzeczywistnienie sacrum w aspekcie strukturalnym, słownym i czynnościowym. W zgodzie z tak wytyczonymi celami pozostaje hierotopograficzna refleksja, która również oscyluje wokół trzech typów przestrzeni publicznej, gdyż w rozprawie poczyniony został wyraźny podział na strefy, pośród których znalazły się tzw. punkty (np. budowle i pomniki), pasma (np. sieci dróg i ulic) i powierzchnie (np. wzniesienia, place miejskie), dodatkowo sfunkcjonalizowane - ukazane w służbie dystrybucji ruchu, celebracji, turystyki i rekreacji oraz edukacji. W tym zakresie czytelnik ma do dyspozycji szczegółowe rejestry budowli, pomników, dróg, ulic i innych form upamiętniania, zebrane w tabelach, których wykaz znajduje się na stronie 362 . Warto nadmienić, że istotnym obszarem badań autorskich, zresztą dotąd niezbyt często eksplorowanym w aspekcie sakralnym i socjoprzestrzennym, stała się także wieś, która podobnie jak miasto znalazła należne sobie miejsce w rozważaniach, przez co znacząco został poszerzony zakres rozpatrywanego problemu.

Autorka studium przyjęła założenie, jak się zdaje, pozornie tylko słuszne, że religia (w tym przypadku chrześcijaństwo i konfesja rzymskokatolicka) jest niekwestionowanie integralną częścią nowoczesnego polskiego społeczeństwa, oraz, co już bardziej trafne (lecz tylko z ogólnokulturowego punktu widzenia), że na proces sakralizacji oddziałują zbiorowe poglądy, predylekcje oraz możliwości grupy, którą autorka mało precyzyjnie określa jako religijną, przywołując pojemne semantycznie miano homo religiosus. Obie te koncepcyjne ramy budzą wątpliwości, choćby ze względu na ich zbyt kategoryczną eksplikację, bo tak, jak nie można traktować religii jako elementu nowoczesnego społeczeństwa - szczególnie w aspekcie długotrwałej, notowanej od czasów oświeceniowych po dobę industrializacji i w dalszym ciągu postępującej desakralizacji - tak też nie powinno się całej wspólnoty (tu: narodowej - polskiej) definiować a priori 
w kategoriach religijnych, tym bardziej w odniesieniu do jednego tylko wyznania: rzymskiego katolicyzmu.

Autorka wprawdzie dostrzega procesy eliminacji i zmniejszania wpływu religii na życie społeczne czy polityczne, jednak w kilku wypowiedziach dystansuje się wobec tego zjawiska, pragnąc udowodnić postęp sakralizacji i znaczące pomniejszenie tendencji desakralizacyjnych przestrzeni publicznej w Polsce w latach 1989-2013. Szczególnym przykładem są miasta o tak zwanym „czerwonym” rodowodzie (s. 269), jak Gorzów Wielkopolski, w których wcześniej proces sakralizacji przestrzeni był praktycznie niezauważalny (s. 258).

W rozprawie wykorzystano metody badawcze właściwe przede wszystkim geografii religii (dokładnie metodologię badań geografii społeczno-ekonomicznej). Wiele wniosków zostało wysuniętych na podstawie perspektywy historycznej i strategii obserwacyjno-uczestniczącej. Podczas licznych kwerend bibliotecznych oraz badań terenowych Autorka zebrała, uporządkowała i opracowała bogaty materiał faktograficzny. Wypada się jednak upomnieć także o nowocześniejsze rozwiązania metodologiczne. Warte uwagi są np. poszukiwania w sferach socjoimagologicznych. Mimo wszystko, dzięki szerokiemu zastosowaniu teorii i koncepcji wypracowanych w obrębie wybranej metodologii, studium Lucyny Przybylskiej może pretendować do miana pracy o interdyscyplinarnym charakterze.

Książka posiada przemyślaną, spójną strukturę, jej układ jest dość czytelny; całość składa się ze wstępu, siedmiu rozdziałów merytorycznych, zakończenia i bibliografii oraz wykazu rycin, fotografii, tabel. Wprowadzenie wraz z trzema pierwszymi rozdziałami (I: Sakralizacja i desakralizacja we współczesnym świecie; II: Czynniki i uwarunkowania manifestacji religii $w$ przestrzeni; III: Zarys genezy form obiektów religijnych $w$ przestrzeni) stanowi grunt dla właściwych rozważań, ich podbudowę teoretyczno-metodologiczną. Autorka dokonuje tu przeglądu najważniejszej literatury przedmiotu (rodzimej i zagranicznej), przytacza definicje uświęcenia i przestrzeni, prezentuje zakres, cele własnych badań i przyjętą metodologię oraz dokonuje stopniowej introdukcji w skomplikowaną materię sakralizacji i desakralizacji, czynników i uwarunkowań manifestacji religii w przestrzeni, genezy obiektów i zjawisk religijnych w aspekcie przestrzennym.

Kolejne rozdziały o empirycznym charakterze (IV: Sakralizacja architektoniczna; V: Sakralizacja (tym)czasowa; VI: Sakralizacja nomen- 
klaturowa) prezentują wyniki autorskich badań nad projekcjami i manifestacjami religii w przestrzeni publicznej. Autorka pokazuje przykłady kościołów, kaplic, pomników, krzyży przydrożnych oraz sakralnych manifestacji w górach i na wzniesieniach; zwraca uwagę na fenomen pielgrzymek, procesji, marszy i innych zachowań religijnych; omawia nazwy ulic, patronów miast i szkół, podnosi kwestię tablic, banerów i napisów będących wprost przekaźnikami treści wiary wyznawanej przez ich autorów czy deklarujących przywiązanie do niej. Rozważania Przybylskiej wieńczy syntetyczny przegląd opinii na interesujący ją temat. Przedstawia ona kontrowersje, jakie wywołuje sakralizacja miejsc publicznych w Polsce (VII: Spory wokót sakralizacji). Skupia się przede wszystkim na problematycznym zagadnieniu krzyży powypadkowych oraz na wybranych elementach dyskursu publicznego o obecności religii i jej znaków w przestrzeni wspólnotowej. Zastanawia się, czy jest to słuszne czy przeciwnie - niekonieczne lub nawet niepożądane.

Zakończenie zostało zaprojektowane raczej zaskakująco dla czytelnika: jako ekspozycja jednoznacznych tez potwierdzających poglądy Autorki, która pozytywnie wartościuje obecność znaków religijnych w przestrzeni publicznej - i to związanych z jedną denominacją chrześcijańską, rzymskim katolicyzmem - oraz jest przekonana o intensyfikacji tego zjawiska w Polsce w latach 1989-2013, mimo że przytaczany w książce materiał faktograficzny nie daje takiej pewności. Już w pierwszych frazach zakończenia czytamy:

Celem niniejszej pracy było udowodnienie hipotezy, że w latach 1989-2013 nastąpiło w Polsce wypełnienie przestrzeni publicznych obiektami i zjawiskami związanymi $\mathrm{z}$ religią, który to proces nazwano sakralizacją. Hipotezę tę zweryfikowano pozytywnie. Zaobserwowano zarówno wzrost obecności, jak i różnorodności form manifestacji religii po 1989 roku w każdym z trzech analizowanych typów sakralizacji. W polskim krajobrazie wzrosła liczba, popularnych od wielu wieków, parafialnych kościołów i kaplic Kościoła rzymskokatolickiego. Prawdopodobnie zwiększyła się liczba krzyży powypadkowych, a krzyże i kapliczki nadal stoją przy polskich drogach. Trudno w górach i na wzniesieniach w pasie wyżyn i nizin nie spotkać krzyża, tablicy czy kapliczki upamiętniających jakieś wydarzenie o charakterze religijnym, często Jubileusz 2 tys. lat chrześcijaństwa. Wszystkie najważniejsze - w sensie najwyższe lub znaczące dla lokalnej społeczności - szczyty, zostały zsakralizowane dawniej lub w ostatnich dekadach większymi lub mniejszymi obiektami odsyłającymi do sfery sacrum. Ponadto od lat 90. XX wieku dużą popularnością cieszą się inicjatywy wznoszenia pomników papieża Jana Pawła II (s. 331-332). 
Oczywiście pod wieloma względami należy uznać rezultaty badań za rzeczywiste i bezdyskusyjne, nie można wszak zaprzeczyć, że wiele ze wskazanych różnorodnych procesów sakralizacyjnych zaszło i wciąż zachodzi, jednak, jak się wydaje, nie w tak ogólnej i unifikującej perspektywie oraz wielkiej skali, w jakiej chce je widzieć Autorka. Poniekąd właśnie słabością rozprawy jest redukcja obrazu społeczeństwa polskiego do jednej tylko konfesji rzymskokatolickiej i tradycji etnonarodowej, a także wyłaniające się z tego obrazu formy sakralizacji, które mają obejmować cały kraj. Warto podkreślić, że w polskim społeczeństwie w równie dużym stopniu następują procesy odwrotne, wprost świadczące o postępującej desakralizacji miejsc publicznych, laicyzacji i sekularyzacji w sferze mentalnej oraz instytucjonalnej. Jaskrawych w tym zakresie egzemplifikacji szukać należy przede wszystkim w zjawiskach od jakiegoś czasu obecnych nie tylko w zachodniej Europie, ale też w Polsce, tj. w obrocie nieruchomościami sakralnymi (np. sprzedaż świątyń ewangelickich w Połajewie, w Śliwicach koło Tucholi) czy wynajmie - udostępnianiu przestrzeni sakralnych na cele zgoła dalekie od pierwotnych założeń (np. przegląd muzyki techno na Festiwalu Electrocity w Lubiążu w budynku Opactwa Cysterskiego) oraz w wielu innych tendencjach i formach celebracji zastępujących czy spychających na margines dotychczasowe święta i tradycje (dość przywołać choćby święcący przez ostatnie lata tryumf Halloween).

Godzi się również przypomnieć o niejednorodności Polaków pod względem religijnym, wyznaniowym czy kulturowym, nie wspominając już o żyjących w Polsce mniejszościach, co jeszcze bardziej komplikuje postawiony problem, a co w rozprawie nie zostało dostatecznie ukazane czy choćby mocniej zasygnalizowane. Takie uproszczone podejście dziwi tym bardziej, że Autorka ma świadomość zróżnicowania - w jednym z fragmentów rozprawy przytacza, choć zdawkowo, aktualne informacje o zarejestrowanych związkach wyznaniowych w Polsce oraz historyczne dane statystyczne na temat struktury wyznaniowej kraju (wymienieni zostali grekokatolicy, prawosławni, ewangelicy, wyznawcy religii mojżeszowej) (s. 75-76). A jednak dalej Lucyna Przybylska stwierdza:

Dawniej - tak jak i obecnie - w Polsce w strukturze wyznaniowej wyznania chrześcijańskie dominowały wśród społeczeństwa (przynależność deklarowało ok. 90\% ludzi), jednak w wyniku eksterminacji ludności żydowskiej, migracji ludności oraz zmian gra- 
nic w pierwszych latach po drugiej wojnie światowej Polska stała się krajem homogenicznym pod względem religijnym (s. 75-76).

Ta opinia pozwala Autorce nie zauważać odmiennego kulturowo regionu Podlasia, na którym dominuje konfesja prawosławna i widoczne są elementy religijnej kultury muzułmańskich Tatarów (Związek Tatarów RP), nie wspominając o odradzającej się dziś wspólnocie żydowskiej. Na tym terenie przestrzeń publiczną znaczą krzyże prawosławne, kapliczki czy ważne dla kultu religijnego miejsca, jak np. Góra Grabarka, inne klasztory czy świątynie parafialne, nawet pustelnie (pustelnia pw. św. św. Antoniego i Teodozego Pieczerskich w Odrynkach), a również muzułmańskie meczety w Bohonikach, Kruszynianach, Gdańsku. Coraz częściej o tym bogactwie kulturowym mówi się w ogólnopolskich mediach - chociażby przy okazji świąt czy różnych okolicznościowych uroczystości. Przecież aktualna pozostaje maksyma św. Pawła o pięknie różnorodności w jedności oraz urodzie jedności w różnorodności (Rz 12,4-5).

Pomimo przedstawionych zastrzeżeń, książka Lucyny Przybylskiej jest wartościowa, stanowi ciekawe opracowanie problemu miejsca, roli, projekcji religii w nowoczesnym państwie i społeczeństwie; studium przypominające czy też eksponujące czynniki, fakty kształtujące świadomość grupy, wskazujące na jej poglądy, potrzeby, dążenia, które określają i utrwalają wspólnotową tożsamość oraz przynależność. Na uznanie zasługuje wieloaspektowa analiza procesu sakralizacji, który został potraktowany jako trwałe i otwarte nastawienie oraz świadome uzewnętrznienie stosunku wobec religii na przykładzie zbiorowości polskiej wyznania rzymskokatolickiego. Imponujący jest także zasób zgromadzonych opracowań, źródeł i materiałów faktograficznych, z których Autorka szeroko i umiejętnie (choć nie zawsze w pełni krytycznie) korzysta. Publikacja jest godna polecenia zarówno ze względu na podjętą problematykę, jak i na próbę interdyscyplinarnego ujęcia. Z pewnością będzie ona pomocną lekturą dla tych czytelników, których zainteresowania oscylują wokół zachodzących procesów i zjawisk emanacji sacrum we współczesnym świecie. 